\title{
PROCUREMENT AND INVENTORY LOGISTICS OPTIMIZATION OF SMALL TRADE ENTERPRISES IN BELARUS
}

\author{
OPTYMALIZACJA LOGISTYKI ZAOPATRZENIA I ZAPASÓW \\ MAŁYCH PRZEDSIĘBIORSTW HANDLOWYCH NA BIAŁORUSI
}

https://doi.org/10.34739/zn.2019.48.06

Yauheni Kazheunikau

Belarus, Sukhoi State Technical University of Gomel, Economy and Management by Industries ORCID: 0000-0002-9986-1868, e-mail:k-e-a@gstu.by

\begin{abstract}
The article describes the state of logistics of small trade enterprises in Belarus, offers an algorithm for optimizing their procurement and inventory, as well as provides an evaluation of results of such optimization for small trade enterprise. The purpose of the study is to improve the procurement and inventory logistics in trade. Research methods: statistical method, analysis and synthesis.

Keywords: Belarus, trade, logistics, procurement, inventory, optimization

Streszczenie: Opisano stan logistycznej działalności małych firm handlowych na Białorusi oraz przedstawiono model algorytmu optymalizacji zakupów i zapasów. Oszacowano wyniki przedstawionego modelu optymizacji dla małej firmy handlowej. Celem badania była poprawa logistyki zakupów i zapasów w handlu. Metody badawcze: analiza i synteza, statystyki.
\end{abstract}

Słowa kluczowe: Białoruś, handel, logistyka, zakupy, zapasy, optymizacja

\section{Introduction}

A logistical approach in solving economic challenges that business entities face, has been actively developing in the Republic of Belarus since the 1990-s (Kozhevnikov, 2014). It is connected with both switching to a market-based economy and the necessity of its fundamental changing and modernization. Industrial and manufacturing, agricultural, commercial and transport companies have shown very different degrees of receptivity to the logistical approach. Large and medium-sized manufacturing companies, that transformed from Soviet Union enterprises, only partially and fragmentarily managed to implement the principles of classical logistics, business logistics and even less neologistics (Kozhevnikov, 2014). Large wholesale and retail trade networks, including large transport companies, have appeared to be the leaders in applying logistical methods and principles. However, small wholesale and retail companies, small networks and shops have not yet implemented major logistical approaches. At the same time, efforts have been made to develop small and medium-sized businesses, including the ones in the trade sphere. In particular, the following programmes and strategies have been adopted in the latest three years:

- Small and Medium Entrepreneurship Development Programme in the Republic of Belarus for 2016-2020 (approved by Resolution N149 of the Council of Ministers of the Republic of Belarus, dated 23 February 2016);

- Social and Economic Development Programme in the Republic of Belarus for 2016-2020 (approved by the Decree N466 of the President of the Republic of Belarus, dated 15 December 2016);

- Small and Medium Entrepreneurship Development Strategy 'Belarus is the country of successful entrepreneurship' for the period until 2030 (approved by Resolution N743 of the Council of Ministers of the Republic of Belarus, dated 17 October 2018).

That is why from scientific and practical points of view, we find it interesting to explore theoretical and practical problems, and the challenges and methods of solving them using the example of procurement and inventory logistics of small Belarusian wholesale and retail trade companies. 


\section{Theoretical approaches to analyzing procurement and inventory logistics}

From our point of view, analyzing logistics in any sphere of economy requires profound theoretical foundation. In our study, modern marketing theory will lay at the heart of it.

Among up-to-date marketing theory concepts, we would like to single out holistic marketing concepts by Philip Kotler and Kevin Lane Keller (Kotler, 2012). They examined all the aspects of the functioning of organizations in their integrity, systemacy, interaction and complementarity. For our study, it is particularly vital that in their view holistic marketing embraces not only distribution channels, but also goods procurement. Kotler and Keller see marketing not as an additional function, but as a driving force of an organization.

Nowadays, based on the paradigm of Kotler and Keller, new concepts, forms and tools of holistic marketing constantly appear (Kozlova, 2011; Krikovtsev, 2011; Zagorna, 2012; Borzakovs'ka, 2013; Zhilinskaya, 2014 Illyashhenko 2016) most of which, to a large extent, can be applied to the logistics of trade enterprises.

Theoretical approaches and practical recommendations concerning the system of managing procurement and inventory based on logistic principles are extensively covered in both scientific (Chebotaev, 2012; Grigor'ev, 2012; Margunova, 2012; Protsenko, 2012) and educational (Tebekin, 2011; Nemogaj, 2013; Prosvetov, 2014; Volgin, 2014; Volochienko, 2014; Anikina, 2015; Sergeev, 2015; Stepanov, 2015; Afanasenko, 2016; Grigor'ev, 2016; Kamenev, 2016) Russian-speaking literature.

Although, as a rule, the given publications cover a wider spectrum of economic spheres of activity, not only focusing on trade. Besides, none of them touch upon the specific character of the functioning of small trade enterprises.

Questions relating to the methodology of analyzing and planning trade procurement and inventory have been researched by many authors and are widely represented in Russian-speaking scientific press and literature (Akopov, 2001; Levi, 2001; Vellkhoff, 2004; Shrabfeder, 2006; Zubkova, 2006; Pikalov, 2014; Buzukova, 2015; Krok, 2015; Novoselova, 2016; Akhmetgareeva, 2018; Plechkov, 2018). However, the methods described cannot always be applied to small trade companies as diversity of class, groups and categories of their goods, as well as the complexity of capital flows and their low intensity, hinder procurement and inventory logistics and make their optimization more complicated.

\section{Procurement and inventory logistics optimization algorithm for a small trade company}

Scientific and educational literature sources on economic and mathematical modelling and logistics provide various definitions of the word 'inventory'. Without seeking to use a detailed and systematic definition of this concept, we see 'inventory' as temporarily unused material resources or goods, which will be used later in production, sale or consumption. We have been applying the abovementioned definition for a considerable time in economic and mathematical modelling (Kozhevnikov, 2004).

In logistics everything is viewed as related to material flow movement, therefore, 'inventory' is 'a material flow, waiting to be used as a commodity for production or sold as goods (Vorozhejkina, 2007, p. 31 ). It means that inventory is a temporarily halted material flow of a kind. It appears due to time inconsistencies with demand and consumption on the one hand, and supply, availability and provision on the other.

In a trade company, excessive investment into goods inventory decreases its turnover and increases working capital, necessity in loans in order to pay salaries to sales workers, payments to vendors for the goods supplied, as well as current expenses.

Freezing funds invested in goods inventory reduces the possibility of increasing a company's profitability by means of using financial resources for other, more profitable areas of trade activities. Apart from that, excessive (from the point of view of its realization) goods inventory requires large expenditure on its selling at reduced prices, renting additional storage facilities and paying taxes on its storage.

Lack of investment also has many adverse consequences. In this case trade companies may lack required goods, which leads to potential clients loss, decrease in goods turnover volume, increase in cost per 1 Belarusian ruble of goods turnover, as they have to pay sales workers salaries that were not actually earned, as well as maintenance costs of idle equipment.

Under the guidance of the author of this article, a master candidate in Economic sciences, Tatiana Melnikova, developed the method for optimizing procurement and maintaining an optimum level of goods inventory and tested it on several small trade organizations. 
The method's algorithm involved the following stages:

1. Building and adjusting an assortment matrix for the company's logistics.

2. Selecting the most favorable terms of goods procurement and delivery.

3. Calculating the optimum interval between deliveries from each supplier of goods.

4. Calculating the optimum amount of inventory between deliveries for each name of the goods.

5. Compiling the optimum schedule of deliveries.

\section{Consider each stage in greater detail}

1. Building and adjusting an assortment matrix for the company's logistics.

An assortment matrix is the basis for managing trade and warehouse inventory in a company. An assortment matrix must be characterized by the depth and breadth of assortment so as to satisfy customers' necessities, but at the same time, it must contribute to better utilization of financial resources. An unreasonably broad assortment may lead to an increase in the average cost of the goods inventory.

Building an assortment matrix allows to identify not only what goods need to be delivered to the store, but also how efficient the sale of these goods must be, as well as how reasonable it is to cooperate with the suppliers of these goods.

The proposed method allows to build and adjust the assortment matrix based on $A B C$ analysis using the goods inventory ranking principle, Gross Margin Return On Investment (GMROI) and combining both approaches in the system. The Gross Margin Return on a trade company's own investment characterizes the profitability of an inventory investment. GMROI is calculated as the ratio of Gross Profit for the previous year to the Average Cost of the goods inventory for the same period. GMROI makes it possible to identify goods classes, groups, categories and items of trade inventory, which don't generate revenue for the company. Several approaches could be used to identify them:

- Setting the minimum target of GMROI. We set the minimum GMROI target of $100 \%$ for the period analyzed.

- Deviation from GMROI of a trade organization by a certain value. We set the maximum deviation from GMROI of $50 \% \%$ for the period analyzed.

- Deviation of a structure in a trade category or subcategory by a certain value.
2. Choosing the most favourable terms of goods procurement and delivery.

Unfortunately, Belarusian suppliers often do not accept supply orders for 1 item only. Yet, even if they do, the delivery conditions for such an order do not allow for selling it for a good price. To meet suppliers' requirements and to receive goods for 'adequate prices', companies have to order a certain volume of goods, a so-called target size of an order. There are different ways to represent the target size. For instance, it may be represented in quantitative terms, as a total volume of items to be ordered. Most suppliers set the minimum price for an order (based on replacement cost of the goods procured).

An order cycle is the average time (usually counted in days) needed for selling, transporting or other use of goods in the quantity sufficient for receiving the target size of an order from the main supplier of this category of goods.

The quantity of each kind of goods required has to be identified for each supplier. Besides, suppliers tend to set the day for accepting supply requests, which must also be taken into consideration when calculating the number of days between ordering goods.

The suggested algorithm of choosing terms of goods procurement and delivery envisages:

- An opportunity to obtain an installment payment option;

- An opportunity to pay from a company's own resources;

- An opportunity to attract external investment to pay for goods with different interest rates on loans;

- Combining all the above-mentioned options.

3. Calculating the optimum interval between deliveries from each supplier of goods.

Based on the minimum price for an order set by a supplier, as well as installment duration and order placement counted in days we can calculate:

- Total goods turnover for a period for each supplier;

- Anticipated daily average goods turnover for a period for each supplier.

Taking this into consideration, we can calculate the optimum interval between deliveries for each supplier in days.

4. Calculating the optimum amount of inventory between deliveries for each name of goods. 
To obtain this value we need to calculate the following:

- Turnover of each type of goods of each category of goods in days. Turnover period or turnover in days shows the number of days it took to realize the average inventory in a reporting period. It is calculated in accordance with the formula:

$$
\mathrm{P}=\frac{\mathrm{GI}^{a v}}{\mathrm{GT}},
$$

Where:

$\mathbf{P}$ is the turnover period;

$\mathrm{GI}^{a v}$ is the average goods inventory;

GT is actual daily turnover of goods for the same period.

The required inventory, calculated in the number of items

- Optimum interval between deliveries for each name of goods, counted in days

- The amount of redundant inventory, counted in the number of items.

In this way we get a range of goods inventory broken down by suppliers and commodity items with minimum and maximum limitations.

5. Making an optimum schedule of deliveries. We suggest forming the schedule in the following way:

- Based on stabilizing the accounts payable and excluding breaches of contractual liabilities;

- Based on reducing goods inventory without decreasing their assortment;

- Based on reducing a company's own investment in the goods inventory;

- Based on reducing or excluding external investment;

- Based on growth of gross profitability of a company's own investment.

The described algorithm of optimizing procurement and inventory logistics optimization of small trade enterprises at certain stages is of an iterated nature. Therefore, it is based on consistent repetition of calculating procedures to get a more reasonable and precise total. See the results of optimizing calculations for several small Belarusian trade enterprises below.

\section{Procurement and inventory optimization results for specific Belarusian trade enterprises}

Applicability and effectiveness of any algorithm, especially the one dealing with optimization, can be proven only by carrying out practical calculations of figures of a specific company. Under the guidance of the author of this article, a master candidate in Economic sciences, Tatiana Melnikova, has carried out such calculations based on limited liability companies 'Detski' and 'BlekPlast' and a private trade unitary enterprise 'TransCommerce-K'. LLC 'Detski' specializes in retail trade of non-food items. The company operates in 3 non-specialized chain stores situated in several districts of Gomel. The company's assortment is mainly represented by goods for children: toys (more than 60\%), clothes (more than 20\%) and other goods. We chose this enterprise because its trade and warehouse inventory take up $90 \%$ of its operating capital structure. Implementing procurement and inventory logistics in accordance with our method has allowed:

1. To optimize order and delivery volume, including the amount of goods (as a rule, reducing it) and the interval between deliveries (as a rule, reducing the number of days between deliveries).

2. To form a schedule of deliveries, reducing the cost of the goods inventory to an optimum level without decreasing the assortment of a trade facility (see Fig. 1).

Besides, the goods supply request will only comprise the trade units and their quantity, that are necessary for the continuous work of a trade facility. Moreover, this will allow to timely identify the items that remain unsold, in order to control and keep the average goods inventory at the same level.

3. To reduce the risk of breaches of contractual liabilities related to breaking the deadlines of payments for goods and to optimize the accounts payable to goods suppliers by a trade company, avoiding overdue payables (see Fig. 2).

4. To achieve the growth of retail turnover (for a specific supplier by $13 \%$ ), stabilizing the accounts payable and keeping their value at the same level (see Fig. 3).

5. To optimize the company's own investment in the goods inventory (see Fig. 4), ensuring reduction of the average cost of the goods inventory for a mid-year by half. 


\section{BYN, thousands}

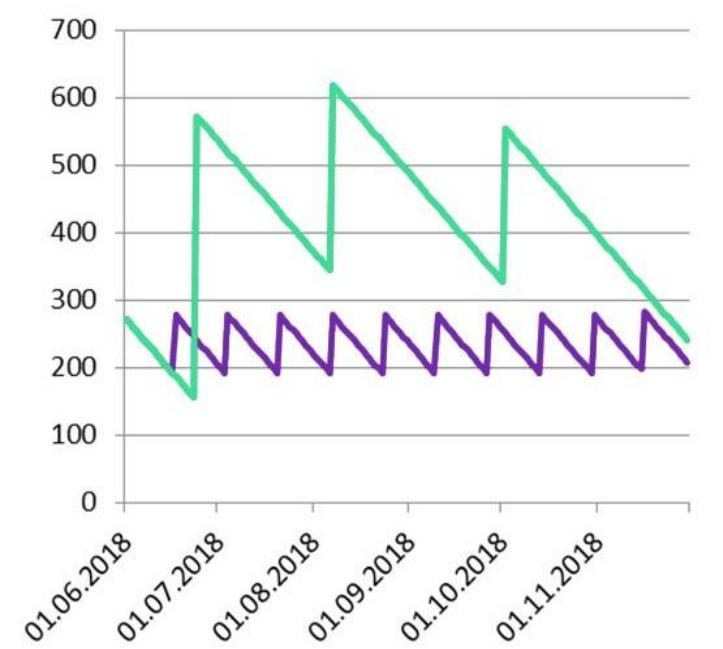

The cost of goods inventory with the delivery inventory schedule

Figure 1. Fluctuation in the cost of the goods inventory company

Source: own calculation on the basis of research results.

\section{BYN, thousands}

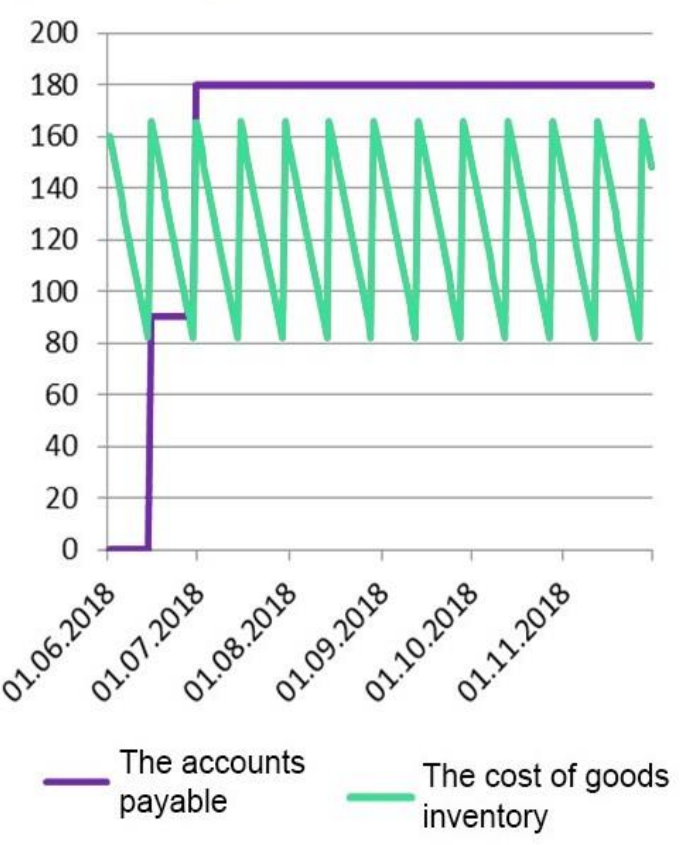

Figure 3. The levels of the accounts payable and the cost of the goods inventory with retail turnover increased by $13 \%$

Source: own calculation on the basis of research results.
BYN, thousands

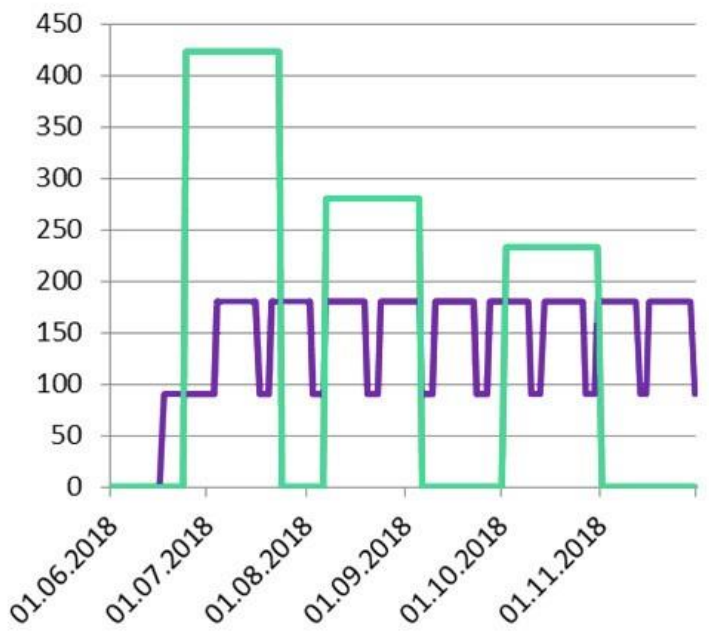

The accounts payble with the delivery The accounts payable schedule

Figure 2. Fluctuation in the accounts payable in the trade Source: own calculation on the basis of research results

\section{BYN, thousands}

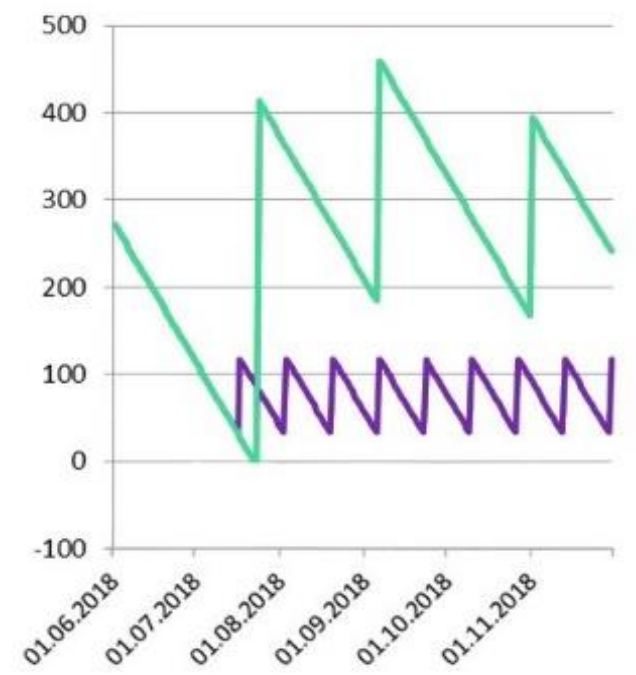

The company's own investment in inventory with the delivery schedule

The company's own investment in inventory

Figure 4. Fluctuation of the company's own investment in the goods inventory

Source: own calculation on the basis of research results. 
6. To take maximum advantage of installment payment plans provided by goods suppliers (manufacturers and wholesale companies), minimizing a company's own investment in goods and interest on credit of external investors. According to our calculations, it is possible to find such optimum installment plans to pay the suppliers, that there would be no necessity to pay interest on bank credit.

7. To buy and sell the goods of some suppliers without investing the company's own funds, as the retail turnover for an installment payment period exceeds the minimum required amount of the goods inventory for this supplier (see Fig. 5).

\section{BYN, thousands}

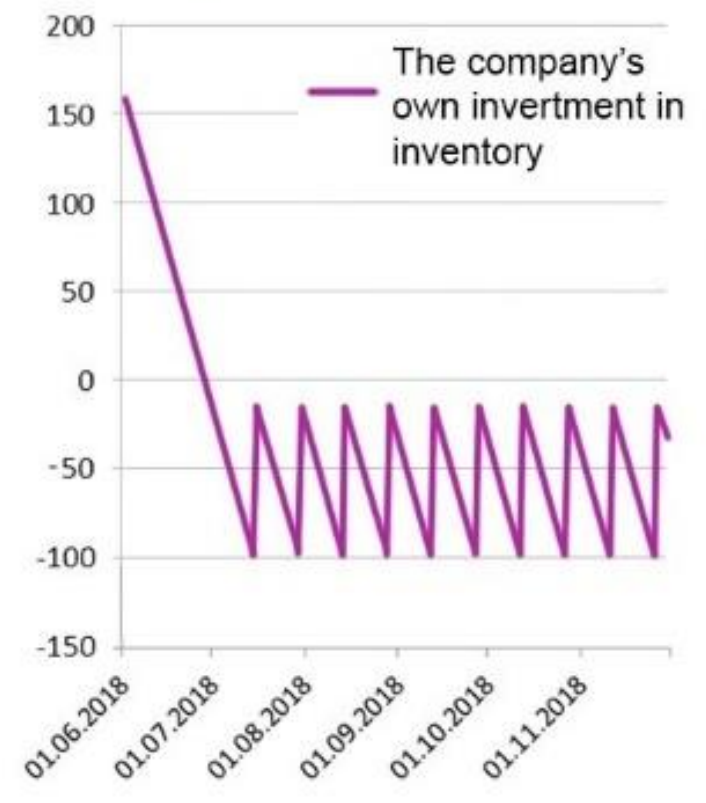

Figure 5. Volume of the company's own investment with a retail turnover increased by $13 \%$ Source: own calculation on the basis of research results.

8. To ensure significant growth of GMROI for some suppliers. For instance, according to our calculations, this indicator for a specific goods supplier increased by $75.31 \%$.

9. To ensure reduction of the trade margin and, therefore, retail prices, while retaining the gross income of a trade company and increasing GMROI.

Considering the purchasing power of the population of the Republic of Belarus and the high level of competition among Belarusian trade companies, the last factor is of particular importance from both an economic and a social standpoint.

\section{Summary}

The purchasing power of the population and a high level of competition among trade companies in the Republic of Belarus, as well as the presence of large local and foreign retail chains force small and medium-sized trade companies to search for various ways of improving their financial situation and logistics.

1. The state of procurement and commercial activities of small Belarusian trade companies often does not allow building a favourable pricing policy and an assortment strategy, as well as a stable system of planning and management.

2. Logistics of small Belarusian trade companies, where it exists as such, is characterized by partial and fragmentary use of certain tools of classic logistics or business logistics, without reaching the level of neologistics.

3. Procurement and inventory logistics of small trade companies of Belarus requires substantial improvement, in our opinion, particularly by implementing optimization.

4. Planning, accounting, control and goods inventory analysis are carried out with the help of modern computerized tools and information technologies. However, many software products used in small trade companies tend to form supply requests based on reaching a certain minimum level of the goods inventory. Therefore, this approach does not implement optimization principles profoundly and systemically.

5. It is practical to optimize procurement and inventory logistics based on building an assortment matrix, which constitutes a multi-levelled structure of the goods inventory organized in accordance with the commodity classification system.

6. Methods of building an assortment matrix in procurement and inventory logistics can be implemented based on $A B C$ analysis, using the goods inventory ranking principle, on Gross Margin Return On Investment (GMROI) and on combining both approaches in the system.

7. Optimizing procurement and inventory logistics of small trade companies allows to substantially improve the financial and economic situation by means of:

- Reducing a company's own investment in the goods inventory and trading activity in general;

- Substantially reducing the average cost of the goods inventory, without decreasing the assortment of a trade facility;

- Stabilizing or decreasing the accounts payable and, therefore, lowering the risks of breaches of contractual liabilities related to breaking payment deadlines and penalties; 
- Taking maximum advantage of installment payment plans provided by goods suppliers (manufacturers and wholesale companies);

- Reducing or even refraining from external investors, particularly from the banking sector, in providing procurement and maintaining the goods inventory.

In the end, this will allow to considerably increase the competitive capacity of small business in the retail trade sector of the Belarusian economy, to ensure financial and economic stability, sustainability and active development of small trade companies.

\section{References}

Afanasenko I.D., Borisova V.V. (2016). Logistika snabzheniya. SPb.: Piter.

Akhmetgareeva A.A., Yu.S. Valeeva, M.V. Efremova, V.A. Sajdasheva, O.V. Chkalova. (2018). Razrabotka i vnedrenie innovatsionnykh tekhnologij v sistemu upravleniya predpriyatiyami roznichnoj torgovli v usloviyakh setevizatsii mezhdunarodnogo ehkonomicheskogo prostranstva, Izd-vo KnoRus.

Akopov V.S. (2016). Organizatsiya marketingovogo upravle-niya torgovym protsessom (na primere seti magazinov roznichnoj torgovli), Marketing $v$ Rossii i za rubezhom, № 6 .

Anikina B.A. (2015). Logistika i upravlenie tsepyami postavok. Teoriya i praktika. Osnovnye i obespechivayushhie funktsional'nye podsistemy logistiki. Uchebnik. Anikina B.A., T.A. Rodkina. M.: Prospekt.

Borzakovs'ka L.V. (2013). Kontseptsiya kholistichnogo marketingu: sutnist' ta teoretichne pidgruntya. Marketing i menedzhment innovatsij. № 2. p. 85-94.

Buzukova, E.A. (2016). Zakupki i postavshhiki, Kurs upravleniya assortimentom $\mathrm{v}$ roznitse, Moscow, Izd-vo Piter.

Chebotaev, A.A. (2012). Logistika i menedzhment tovarodvizheniya. A.A. Chebotaev, D.A. Chebotaev. M.: Ehkonomika.

Grigor'ev, M.N. (2012). Kommercheskaya logistika. Teoriya i praktika. Grigor'ev, S.A. Uvarov, V.V. Tkach. M.: Yurajt.

Grigor'ev, M.N. (2016). Logistika. Uchebnik. M.N. Grigor'ev, S.A. Uvarov. M.: Yurajt.

Illyashhenko N.S. (2011). Organizatsijno-ehkonomichni zasadi innovatsijnogo marketingu promislovikh pidpriestv: monografiya. Sumi: «Vid-voSumDU».

Kamenev, N.G. (2016). Logistika. Uchebnoe posobie. M.: Kurs.

Kotler F. (2012). Marketing, menedzhment. Ehkspress-kurs [3-d edition]. F. Kotler, K.L Keller. Piter.

Kozhevnikov E.A. (2014). Sovershenstvovanie podkhodov i printsipov logisticheskoj deyatel'nosti belorusskikh proizvodstvennykh predpriyatij.
«Modern Marketing and Logistics - globalne wyzwania». I Polska, Uniwersytet Przyrodniczo-Humanistyczny w Siedlcach, Siedlce.

Kozhevnikov E.A. (2014). Perspektivy razvitiya belorusskikh agropredpriyatij na logisticheskikh printsipakh, Aktual'nye voprosy ehkonomicheskogo razvitiya: teoriya i praktika, Sbornik nauchnykh statej, Edition 3, Part I, Gomel, Francisk Skorina Gomel State University.

Kozhevnikov, E.A. (2004). EHkonomiko-matematicheskie metody i modeli, Uchebno-metodicheskij kompleks, Minsk, State Institute of Management and Social Technologies BSU.

Kozlova O.A. (2011). Teoriya i metodologiya formirovaniya rynka organicheskoj prodovol'stvennoj produktsii na osnove kholisticheskogo marketinga: avtoref. dis. d-ra ehkon. nauk: 08.00.05. Omsk. Dostoevsky Omsk State University.

Krikovtsev A.A. Holisticheskij marketing $v$ sisteme biznes-vzaimodejstvij predpriyatij. Marketing i menedzhment innovatsij. 2011. N 4. T. 1, p. 85-89.

Krok G., Sysoeva S.V. (2015). Bol'shaya kniga direktora magazina 2.0., Novye tekhnologii, Moscow, Izdvo Piter.

Levi M., Vejtts B.A. (2001). Osnovy roznichnoj torgovli, Moscow, Izd-vo Piter

Margunova, V.I. (2012). Logistika. M.: TetraSistems.

Nemogaj, N.V. (2013). Logistika. Upravlenie tsepochkami postavok. M.: Tetralit.

Novoselova N.A., Sysoeva S.V. (2016). Operativnoe upravlenie v roznichnoj torgovle, Moscow, Izd-vo Piter.

Pikalov, M. (2016). 7 klyuchej k uspekhu roznichnogo magazina, Sekrety rosta prodazh, Moscow, Izd-vo Piter.

Plechkov, S. (2018). Prodavets na million. Kak prodat' mnogo i dorogo v roznichnom magazine, Moscow, Izd-vo Piter.

Prosvetov, G.I. (2014). Matematicheskie metody v logistike. Zadachi i resheniya. Uchebnoprakticheskoe posobie. M.: Al'fa-press.

Protsenko, O.D. (2012). Logistika i upravlenie tsepyami postavok - vzglyad $v$ budushhee. Makroehkonomicheskij aspekt. O.D. Protsenko, I.O. Protsenko.: Izdatel'skij dom "Delo" RANKHiGS.

Sergeev, V.I. (2015). Logistika snabzheniya. Uchebnik. V.I. Sergeev, I.P. EHI'yashevich. M.: Yurajt.

Shrabfeder, J. (2006). Ehffektivnoe upravlenie zapasami, per. s angl., Moscow, Al'pina Biznes Buks.

Stepanov, V.I. (2015). Logistika. Uchebnik dlya bakalavrov. M.: Prospekt.

Tebekin, A.V. (2011). Logistika. M.: Dashkov i Ko.

Vellkhoff A., Masson ZH. (2004). Merchendajzing, EHffektivnye instrumenty i upravlenie tovarnymi kategoriyami, Izdatel'skij dom Grebennikova.

Volgin, V.V. (2014). Logistika khraneniya tovarov. Prakticheskoe posobie. M.: Dashkov i Ko. 
Volochienko, V.A. (2014). Logistika proizvodstva. Teoriya i praktika. Uchebnik. V.A. Volochienko, R.V. Seryshev. M.: Yurajt.

Vorozhejkina T.M., Ignatov V.D. (2007). Logistika $\checkmark$ APK, Moscow, Kolos S.

Zagorna T.O. (2012). Kontseptsiya kholistichnogo marketingu: dzherela problematiki ta elementi. T.O. Zagorna, A.N. Stasyuk. Marketing i menedzhment innovatsij. № 2, p. 32-38.
Zhilinskaya O.I., Firsova S.G. (2014). Periodizatsiya ehvolyutsii marketingovoj teorii $\mathrm{v}$ kontekste kholisticheskoj kontseptsii. «Modern Marketing and Logistics - globalne wyzwania». I Polska, Uniwersytet Przyrodniczo-Humanistyczny w Siedlcach, Siedlce, p. 109-151.

Zubkova, I.N. (2006). Organizatsiya torgovli neprodovol'stvennymi tovarami, Moscow, Izd-vo Dashkov i Ko. 